\title{
Impact of mandating the research article based evaluation as an assessment for the pre-final year students for effective execution of final year project
}

\author{
Ramarajan Chithiraikannu1, Dhivya $\mathbf{N}^{2}$ \\ ${ }^{1,2}$ Department of Food Technology, Kalasalingam Academy of Research and Education, Krishnankoil. \\ ${ }^{1}$ ramarajan.kamaraj@gmail.com \\ ${ }^{2}$ dhivya@klu.ac.in
}

\begin{abstract}
:
A Literature survey plays a vital role in preparing the students to carry out research-oriented projects in the final year. The influence of equipping the students with a quality reading of research articles before entering their project semester has not received much attention so far. The present study explores this aspect by introducing students to analyze published research articles as a part of internal assessment in the pre-final year. One batch of Students from B.Tech (Food Technology) was given prior practice for literature reading by mandating it as one of the internal assessment for the subject- Oils and Fats Processing technology, while the other class of students went through the conventional assessment system. The influence of adopting the research article based evaluation in the project outcome attainment was compared for both batches of students in the final year. Facilitating the prior literature reading practice helped students to formulate the project objectives more clearly, critically analyze the reported works of previous researchers, identify realistically the expected challenges in the progress of research, avoid repetition of already explored solutions and finally come up with meaning research outcomes within the stipulated time. The study indicates the need for adopting the research article based evaluation as one of the compulsory assessment for students to help gradually develop research aptitude, rather than expecting such skills to form quickly when they enter final year to take up the project.
\end{abstract}

Keywords: research article based evaluation, project outcome

\section{B. Introduction}

Transformation of student's attitude towards engineering education from skillset approach to mark based outcome reduced their involvement in practical skills \& research analysis (Leydens, J. A., \& Lucena, J. C. 2017) which is a key to carry out the independent student project. Although, institutions consider the student project as the key to sustainable development \& social upliftment, student involvement during their project semester is deficient. Although a student shows involvement in their project, insufficient time spent in analyzing literature articles (Natália Almeida et al, 2011) will end up in inefficient attainment of project outcomes.

A Literature review is the knowledge source to define project objectives, collect methodologies, identify research gap, and understand the scope of the project (Hannah Snyder, 2019)

Any successful project would have supported with detailed literature collection (Abdullah Ramdhani et al 2014), whereas, with the current education scenario \& student mentality towards engineering education, they didn't have the required knowledge background, curiosity \& patience to read enough literature to understand the technical findings explained in complex vocabulary to capture necessary inputs relevant to their project. It ends up in a deficient understanding of the project, lack of awareness about expected challenges in conducting experiments (Christoph Muller-Bloch, Johann Kranz (2015) as a result, completion of the project which is not valuable for student, institute as well the society.

As student start practice of reading the literature either in the previous semester or during the project semester, they didn't find sufficient time to overcome the knowledge gap required to understand the literature (Fawaz ali ahamed qaserm and Elrasheed ismail M.Zayid (2019) which end up in identifying not enough literature findings. 
Students may require modification in the assessment method to impart research skills even before entering their project semester (Cynthia J. Finelli and jeffrey E. Froyd, 2019).Hence, students given the prior practice of reading technical research papers may improve their ability to identify research findings relevant to their project in a short time. Thereby a student can prepare a detailed review report with enough literature papers to overcome the knowledge gap required for successful completion of the student project. In the present study, the impact of adopting the new assessment tool- research article based evaluation before project semester was evaluated towards the attainment of project outcome comparing two different batches of students.

\section{Methodologies}

\section{Student selection:}

Students of B.Tech (Food Technology) from two different classes, 2015 and 2016 batch of Pre-project semester were considered in the research. 2016 batch students were given a prior practice for literature reading by mandating it as one of the internal assessment for the subject-Oils and Fats Processing technology, while the other class of students went through the conventional assessment system.

\section{Practice for reading literature article:}

In order to facilitate the reading practice of literature for students to become familiarized with the technical terms, data analysis, and research findings, the new assessment named- literature article based evaluation was incorporated in the assessment pattern as shown in the table.1, for the selected subject with a set of rubrics as shown in the table.2, to evaluate the student's performance \& identify their shortcomings.

In the research article based evaluation, Individual student was given 2 research articles relevant to the subject to identify the research contribution, gap mentioned for future work, compare the difference in methodology, summarize the research outcome and critically evaluate the results and conclusion.

Students were given the demonstration about how to collect the required data from a research article to help them understand the expectations of the proposed evaluation method. Frequent reviews were conducted to evaluate whether the data collected by the students adhere to the expectations given in the rubrics. Slow learners were given an additional time of support to help them understand a research article.
Table 1. Proposed assessment and Conventional assessment pattern

\begin{tabular}{|c|c|}
\hline $\begin{array}{c}\text { Proposed Assessment } \\
\text { Pattern }\end{array}$ & $\begin{array}{c}\text { Conventional } \\
\text { Assessment Pattern }\end{array}$ \\
\hline $\begin{array}{c}\text { Quiz (1No's) } \\
\text { [Each carries 25 questions] }\end{array}$ & Assignments \\
\hline Mini Project & Sessional Examination \\
\hline Seminar & \\
\hline $\begin{array}{c}\text { Research Articles based } \\
\text { Evaluation }\end{array}$ & \\
\hline \begin{tabular}{c} 
Sessional Examination \\
\hline
\end{tabular} & \\
\hline
\end{tabular}

Table 2. Research Article based evaluation Rubrics

\begin{tabular}{|c|c|c|}
\hline \multirow[b]{2}{*}{ Components } & \multicolumn{2}{|c|}{ Mark allotment } \\
\hline & $\begin{array}{c}\text { Maximum } \\
\text { Marks }\end{array}$ & $\begin{array}{r}\text { Allotted } \\
\text { Marks }\end{array}$ \\
\hline $\begin{array}{l}\text { Background } \\
\text { undertaking of topic } \\
\text { based on text } \\
\text { book/class notes }\end{array}$ & 10 & \\
\hline $\begin{array}{l}\text { Research contribution } \\
\text { made in the } \\
\text { article/papers }\end{array}$ & 10 & \\
\hline $\begin{array}{l}\text { Comparison of } \\
\text { difference in research } \\
\text { work/methodology } \\
\text { reported in the article }\end{array}$ & 10 & \\
\hline $\begin{array}{l}\text { Summary of research } \\
\text { outcomes in each } \\
\text { article }\end{array}$ & 5 & \\
\hline $\begin{array}{l}\text { Critical evaluation of } \\
\text { results and } \\
\text { conclusions }\end{array}$ & 15 & \\
\hline $\begin{array}{l}\text { Suggestions for future } \\
\text { work }\end{array}$ & & \\
\hline
\end{tabular}

\section{Conventional assessment pattern:}

In the conventional assessment, Students were evaluated individually for their knowledge capture in the subject matters based on the blooms taxonomy. Both assignments and descriptive examinations are the part of 
conventional assessment. An assignment includes case study, models, quiz, video presentations and seminar.

\section{Analysis of Project Outcomes}

Here we are evaluating the impact of practice given to read a research article towards proper framing and execution of their project during the final year.

Both 2015 and 2016 batch students were taken for this study. Project outcome attainment was compared and analyzed for both batch of students.

2015 batch students were not given any literature reading activity during their academic year, whereas for 2016 batch students, literature reading is taken as one method for evaluating their outcome attainment for oils and fats processing technology course during their pre-final year.
The student's performance in the project was measured using the metrics as shown in the table 3. The metrics framed with a genuine interval that allows comparison of student's performance based on the rubrics used. Each score was then transcribed to an individual student data inline within a larger data file inclusive of all students' performances. Each data line represents the transformation of qualitative data to quantitative data. The Course outcome was analyzed based on the direct assessment using the rubrics framed.

The target for this assessment is each student should score above $\geq 3$ on 5 point scale. For both the $2015 \& 2016$ batch, the target was set as $70 \%$ of students should score above $\geq$ 3 on 5 point scale.

Evaluation

Table 3. Rubrics for project performance evaluation

\begin{tabular}{|c|c|c|c|c|c|}
\hline $\begin{array}{c}\text { Performance } \\
\text { Indicators }\end{array}$ & $\begin{array}{c}\text { Excellent } \\
\text { (5) }\end{array}$ & $\begin{array}{c}\text { Very good } \\
\text { (4) }\end{array}$ & $\begin{array}{c}\text { Good } \\
\text { (3) }\end{array}$ & $\begin{array}{c}\text { Fair } \\
(2)\end{array}$ & $\begin{array}{l}\text { Poor } \\
\text { (1) }\end{array}$ \\
\hline $\begin{array}{lr}\text { (A) Ability of the } \\
\text { student } \\
\text { formulate project } \\
\text { objectives }\end{array}$ & $\begin{array}{l}\text { Student can } \\
\text { frame } \\
\text { conceived } \\
\text { objective. } \\
\text { Objectives } \\
\text { extensively } \\
\text { related } \\
\text { problem domain }\end{array}$ & $\begin{array}{l}\text { Student can } \\
\text { frame stated } \\
\text { objectives. } \\
\text { Objectives } \\
\text { highly related to } \\
\text { problem domain }\end{array}$ & $\begin{array}{l}\text { Student } \\
\text { partially frame } \\
\text { goal } \\
\text { objectives. } \\
\text { Moderately } \\
\text { related to problem } \\
\text { domain }\end{array}$ & $\begin{array}{l}\text { Student doesn't } \\
\text { frame the well- } \\
\text { defined } \\
\text { objective. } \\
\text { somewhat } \\
\text { related to } \\
\text { problem domain }\end{array}$ & $\begin{array}{l}\text { Student cannot } \\
\text { clearly frame the } \\
\text { objectives. Not } \\
\text { related } \\
\text { problem }\end{array}$ \\
\hline $\begin{array}{l}\text { (B) Ability to } \\
\text { analyse the } \\
\text { reported works of } \\
\text { previous } \\
\text { researchers }\end{array}$ & $\begin{array}{l}\text { Student can } \\
\text { Demonstrates } \\
\text { the gap in the } \\
\text { literature } \\
\text { relevant to their } \\
\text { study and makes } \\
\text { a compelling } \\
\text { argument that } \\
\text { the student } \\
\text { research will } \\
\text { address the gap. }\end{array}$ & $\begin{array}{l}\text { Student can use } \\
\text { the literature to } \\
\text { discuss } \\
\text { scholarly trends, } \\
\text { develop } \\
\text { hypotheses, and } \\
\text { identify the gap } \\
\text { in literature their } \\
\text { work } \\
\text { address. }\end{array}$ & $\begin{array}{l}\text { Adequate } \\
\text { coverage of } \\
\text { relevant literature } \\
\text { but weak } \\
\text { connection with } \\
\text { their research } \\
\text { question or thesis. }\end{array}$ & $\begin{array}{l}\text { Relevance of the } \\
\text { presented } \\
\text { literature to the } \\
\text { research } \\
\text { question } \\
\text { somewhat clear. }\end{array}$ & $\begin{array}{l}\text { Relevance of the } \\
\text { presented } \\
\text { literature to the } \\
\text { research } \\
\text { question is } \\
\text { unclear. }\end{array}$ \\
\hline $\begin{array}{l}\text { (C) Meet the } \\
\text { deadline }\end{array}$ & $\begin{array}{l}\text { Completed } \\
100 \% \text { of the } \\
\text { work effectively } \\
\text { on time. }\end{array}$ & $\begin{array}{l}\text { Completed } 90 \% \\
\text { of the work on } \\
\text { time. }\end{array}$ & $\begin{array}{l}\text { Completed } 80 \% \\
\text { of the work on } \\
\text { time. }\end{array}$ & $\begin{array}{l}\text { Completed } 70 \% \\
\text { of the work on } \\
\text { time. }\end{array}$ & $\begin{array}{l}\text { Completed } 60 \% \\
\text { of the work on } \\
\text { time. }\end{array}$ \\
\hline $\begin{array}{l}\text { (D) Assessment of } \\
\text { results based on } \\
\text { the risk and } \\
\text { uncertainty }\end{array}$ & $\begin{array}{l}\text { Meaningful } \\
\text { results obtained } \\
\text { from } \\
\text { sophisticated } \\
\text { data analyses. }\end{array}$ & $\begin{array}{l}\text { Shows good } \\
\text { understanding } \\
\text { of the analytical } \\
\text { methods. } \\
\text { Provides good } \\
\text { arguments for or } \\
\text { against the } \\
\text { hypotheses. }\end{array}$ & 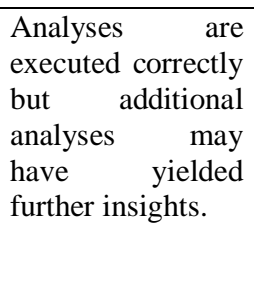 & $\begin{array}{l}\text { Results do } \\
\text { follow from the } \\
\text { analysis and } \\
\text { partial mistakes } \\
\text { are made in } \\
\text { interpretation. }\end{array}$ & $\begin{array}{lr}\text { Results do not } \\
\text { follow from the } \\
\text { analysis and } \\
\text { mistakes are } \\
\text { made in } \\
\text { interpretation. }\end{array}$ \\
\hline
\end{tabular}




\section{Results and Discussion}

The graph fig. 1 shows, the attainment $\%$ of project outcomes by the student's given the literature reading practice is higher than the students followed the conventional assessment system. Since common assessment is followed for both batches of students except the incorporated literature review article based evaluation; we can relate this observed deviation in attainment $\%$ with the influence of literature reading practice. The knowledge capture from the literature reading practice would have helped the students (Christoph Muller-Bloch, Johann Kranz, 2015) of the 2016 batch to be equipped with skillset required to understand the literature article. Hence, the majority of students from the 2016 batch could formulate the project objectives clearly, analyze the reported works of previous researchers to identify the expected challenges in the progress of research, and avoid repetitions thereby complete the project within the deadline.

The observed results justify that the students not given sufficient support to practice read and analyze the literature findings would reduce their attainment of the project outcome.

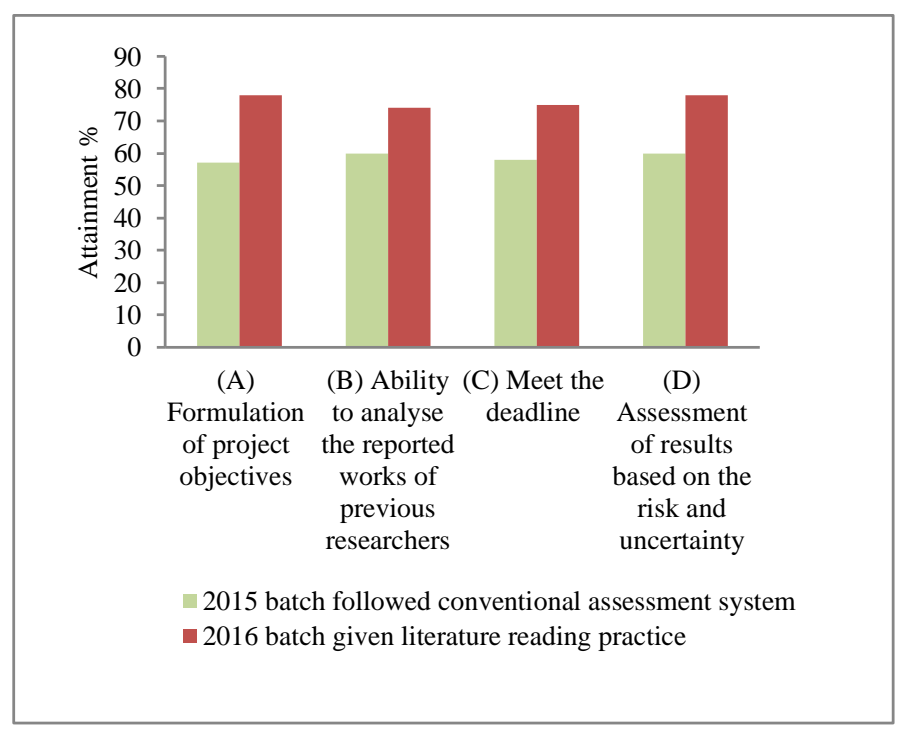

Fig. 1 Project Outcome Attainment for students

\section{E. Conclusion}

Adopting the literature review article based evaluation for the students before starting their project semester supported them to acquire the skill set required to complete their project successfully.

Students require enough time to gradually develop research aptitude which is directly linked to project attainment.

There is a need to adopt the research article based evaluation as one of the compulsory assessment for students to help gradually develop research aptitude, rather than expecting such skills to form quickly when enter final year to take up the project

\section{Acknowledgement}

I sincerely thank my university for given this opportunity to present this study reports for the benefit of students as well as the faculties.

\section{References}

Leydens, J. A., \& Lucena, J. C. (2017). Engineering justice: Transforming engineering education and practice. John Wiley \& Sons.

Natália Almeida, Camila Carrer, José DinisCarvalho, Rui M. Lima (2011), Project Management Guide for Student Project Teams, Conference: International Symposium on Project Approaches in Engineering Education (PAEE'2011): Aligning Engineering Education with Engineering Challenges.

Hannah Snyder(2019), Literature review as a research methodology: An overview and guidelines, Journal of Business Research, 104, 333-339

Abdullah Ramdhani, Muhammad Ali Ramdhani, Abdusy Syakur Amin (2014), Writing a Literature Review Research Paper: A step-by-step approach, International Journal of Basic and Applied Science, 3-1, 47-56.

Christoph Muller-Bloch, Johann Kranz (2015), A Framework for Rigorously Identifying Research Gaps in Qualitative Literature Reviews, Conference: Proceedings of the 36th International Conference on Information Systems (ICIS).

Fawaz ali ahamed qaserm, Elrasheed ismail M.Zayid (2019), the challenges and problems faced by students in the early stage of writing research projects, european journal of special education research, (4)-1, 32-47

Cynthia J. Finelli and Jeffrey E. Froyd(2019), improving student learning in undergraduate engineering education by improving teaching and assessment, advances in engineering education.aee-issue-24-eager-cindy-jeff.pdf 